Editorial

\title{
Specific Exogenetic (External) and Endogenetic (Internal) Effects on Fluvial System Evolution
}

\author{
Jef Vandenberghe ${ }^{1, *(\mathbb{D}}$, David Bridgland ${ }^{2}$ and Xianyan Wang ${ }^{3}(\mathbb{D}$ \\ 1 Institute of Earth Sciences, VU University Amsterdam, 1081HV Amsterdam, The Netherlands \\ 2 Department of Geography, Durham University, South Road, Durham DH1 3LE, UK; \\ d.r.bridgland@durham.ac.uk \\ 3 School of Geography and Ocean Science, Nanjing University, Nanjing 210023, China; \\ xianyanwang@nju.edu.cn \\ * Correspondence: jef.vandenberghe@vu.nl
}

Received: 18 November 2018; Accepted: 21 November 2018; Published: 26 November 2018

check for updates

\begin{abstract}
A collection of papers appears under the title "Special External Effects on Fluvial System Evolution" in the journal, Quaternary. This is a new Special Issue under the aegis of the Fluvial Archives Group (FLAG), illustrating the recent progress made in paleo-fluvial research. These papers highlight the high complexity of the external forcing of fluvial dynamics, and especially, the combined results of several interfering variables. In addition, it appears that the study of fluvial archives cannot be limited to the general and direct effects of external variables, but it also has to include the indirect influences that are regionally variable.
\end{abstract}

Keywords: FLAG; paleo-fluvial; fluvial forcing; fluvial archives

Rivers are excellent witnesses of the dynamics affecting the Earth's surface environments. Their activity is highly sensitive to the external impacts of climate change, base-level change, crustal movements, and human influence, as evidenced over variable temporal and spatial scales. Because these strong relationships, fluvial geomorphology and sedimentology have, in turn, often been applied in order to infer information related to the reconstructions of climate, tectonic (and atectonic) crustal movements, base-level changes, and human activity. The specification of these relationships in terms of the processes involved has always been a crucial point in the study of fluvial archives, and thus a focal point of interest for Fluvial Archives Group (FLAG) research (e.g., [1]). In addition, it was shown several decades ago that the fluvial system is not static, but is affected by its own endogenetic processes, and undergoes its own internal evolution in dynamic equilibrium (e.g., [2,3]). This means that the complexity of the external forcing of fluvial dynamics has to be supplemented with the effects of internal mechanisms. Furthermore, it has been found that, both in internal and external impacts, the delay and feedback effects and threshold crossing often lead to particular results and to more complexity in fluvial evolution (e.g., $[4,5])$.

Until now, there has been focus on evaluating the general impacts of the individual external factors, and more specifically, on disentangling their individual contributions. For instance, there is a recurrent question about how to identify the separate effects of climate and crustal movement on fluvial systems, or how to evaluate the impact of human action in comparison with climate changes. Such basic topics still need further investigation, as is shown by the contributions to this Special Issue. However, it remains a challenge to investigate the combined results of several interfering variables. Furthermore, several cases in the present issue show that we cannot continue to limit the study of fluvial archives to the general and direct effects of external variables. For instance, the climate has an immense impact on the fluvial system, not only in terms of temperature or precipitation, but also 
indirectly, by way of vegetation and frozen ground as intermediaries (e.g., [6,7]). Another example is the impact of crustal movement, which is often specified indirectly through its effects on the steepness of the river gradient, the topographic shape of the river catchment, or the physical properties of the substratum (e.g., [8]). An important result from the earlier years of FLAG research has been the realization that the effects of the various influences, and the style and pattern of the resultant fluvial archives, can vary according to the crustal type, particularly in terms of the susceptibility of different crustal provinces to vertical movement $[9,10]$. In addition, of practical importance, is the impact of human activity, such as land-use change and demographic pressure, in comparison with climatic change (e.g., [11-13]).

Finally, the controlling influences, because of their own complexity, may lead to the opposite, or at least different effects on the fluvial system. For example, cold- and warm-climate conditions have to be differentiated in order to cope with the effects of seasonality, the role of snow cover, and the duration of frost in the soil, while the relative magnitude and frequency of precipitation and temperature greatly affects vegetation. Similarly, crustal movements may have different effects on the fluvial processes as a function of the variety and rate of tectonic movement, or the regionally variable erodibility of the substratum. The regional differences of these indirect impacts may be very important for fluvial evolution.

In summary, the fluvial archive is a rich but also complex source of information. Rivers are reliable recorders of complex dynamics via their sedimentary products and morphological expression, and it is a challenge to contribute step-by-step to the understanding of the operation of the system and its influencing factors. But, in addition to the importance of regional differentiation and the effect of the indirect impacts outlined above, it is desirable to extract the validity of the rules that globally govern the evolution of fluvial systems and are reflected in the fluvial archives.

The present collection of papers under the title "Special External Effects on Fluvial System Evolution" illustrates the recent progress in the direction outlined above. It originally arose from a conference organized by Dr Zhenbo Hu (Lanzhou University, Lanzhou, China) and Prof Xianyan Wang (Nanjing University, Nanjing, China) in the summer of 2017, under the aegis of the Fluvial Archives Group (FLAG), the Quaternary Research Association (QRA), and the Geologists' Association (GA) in the upper and middle reaches of the Yellow River. In their paper, Daley and Cohen stress the significant impacts of regional climatic change above the relatively minor, and rather local-scale effects of intrinsic factors. More specifically, the channel incision at the beginning of the Holocene coincided with a precipitation maximum widely recognized in the otherwise tectonically stable area of subtropical Australia. In contrast, Gao et al. show the internal steering mechanisms apparent in the detailed evolution of an alluvial fan (the Huangshui river, NE Tibetan Plateau), clearly related to the position at the entrance of a subsiding basin, in combination with climatic effects. Other papers illustrate a less equivocally forced fluvial evolution, in which climate impact is interfering with other forcing factors. For instance, Stokes et al. discuss the evolution of the surface of the intramontane Sorbas basin in southern Spain. That surface, originally forming the top of the basin infill, was successively eroded towards a pediment by autogenic processes in the Early Pleistocene, followed by a (external) base-level lowering in the Middle Pleistocene. The next case deals with the tectonic impact of relatively local significance overprinted onto climate changes of a much wider extent in shaping a characteristic example of fluvial morphology. It describes the evolution of the catchment of the Tis(z)a river in the Pannonian Basin, where the differential tectonic subsidence has had a direct impact on the river gradient, and thus on the energy conditions (Vandenberghe et al.). Demir et al. provide a review of the inferred influence of the crustal type within the Eurasian continent on patterns of fluvial-archive preservation over Quaternary timescales, an influence that is shown to have affected landscape evolution in different crustal provinces. At the opposite end of the geographical scale, Cunha et al. attempt to interpret and date a fluvial archaeological context within the lowest (T6) terrace of the Lower Tejo (Tagus), just downstream from the Spain-Portugal border. This concerns a basal gravelly bed beneath silty sands and sandy silts, with the archaeology occurring, in conjunction with the remains of 
large mammals, at the interface between the gravel and the overlying finer-grained sequence. Indeed, the mammals here include some of the youngest examples of megafauna, such as the straight-tusked elephant. Finally, Gibling et al. focus on the impact of different kinds of human activities (for instance, as expressed by land or water management and agriculture) on the modification of channels and floodplains augmented since the beginning of the Holocene.

Funding: This research received no external funding.

Acknowledgments: Financial support for the conference was obtained from the Nanjing and Lanzhou Universities, and from the QRA.

Conflicts of Interest: The authors declare no conflict of interest.

\section{References}

1. Cordier, S.; Bridgland, D. De la géomorphologie fluviale aux archives fluviales (Introduction au numéro spécial). Géomorphol. Relief Process. Environ. 2012, 4, 391-404. [CrossRef]

2. Schumm, S.A.; Parker, R.S. Implications of complex response of drainage systems for Quaternary alluvial stratigraphy. Nat. Phys. Sci. 1973, 243, 99-100. [CrossRef]

3. Vandenberghe, J.; Cordier, S.; Bridgland, D.R. Extrinsic and intrinsic forcing on fluvial development: Understanding natural and anthropogenic influences. Proc. Geol. Assoc. 2010, 121, 107-112. [CrossRef]

4. Schumm, S.A. Geomorphic thresholds: The concept and its applications. Trans. Inst. Br. Geogr. 1979, 4, 485-515. [CrossRef]

5. Vandenberghe, J. A typology of Pleistocene cold-based rivers. Quat. Int. 2001, 79, 111-121. [CrossRef]

6. Vandenberghe, J.; Woo, M.K. Modern and ancient periglacial river types. Prog. Phys. Geogr. 2002, 26, 479-506. [CrossRef]

7. Verstraeten, G.; Broothaerts, N.; Van Loo, M.; Notebaert, B.; D’Haen, K.; Dusar, B.; de Brue, H. Varaibility in fluvial geomorphic response to anthropogenic disturbance. Geomorphology 2017, 294, 20-39. [CrossRef]

8. Rixhon, G.; Demoulin, A. The picturesque Ardennian valleys: Plio-Quaternary incision of the drainage system in the uplifting Ardenne. In Landscapes and Landforms of Belgium and Luxembourg; Demoulin, A., Ed.; Springer: Berlin, Germany, 2018; pp. 159-176.

9. Westaway, R.; Bridgland, D.R.; Mishra, S. Rheological differences between Archaean and younger crust can determine rates of Quaternary vertical motions revealed by fluvial geomorphology. Terra Nova 2003, 15, 287-298. [CrossRef]

10. Bridgland, D.R.; Westaway, R. Preservation patterns of Late Cenozoic fluvial deposits and their implications: Results from IGCP 449. Quat. Int. 2008, 189, 5-38. [CrossRef]

11. Thorndycraft, V.R.; Benito, G. Late Holocene fluvial chronology of Spain: The role of climatic variability and human impact. Catena 2006, 66, 34-41. [CrossRef]

12. Hoffmann, T.; Thorndycraft, V.R.; Brown, A.G.; Coulthard, T.J.; Damnati, B.; Kale, V.S.; Middelkoop, H.; Notebaert, B.; Walling, D. Human impact on fluvial regimes and sediments flux during the Holocene: Review and future research agenda. Glob. Planet. Chang. 2010, 72, 87-98. [CrossRef]

13. Wolf, D.; Seim, A.; Faust, D. Fluvial system response to external forcing and human impact-Late Pleistocene and Holocene fluvial dynamics of the lower Guadalete River in western Andalucía (Spain). Boreas 2014, 43, 422-449. [CrossRef] 